\title{
Pemodelan Inflasi Di Indonesia Menggunakan Pendekatan Model Generalized Autoregressive Conditional Heteroskedasticity (GARCH)
}

Vita Ratnasari, Maulidiah Nitivijaya

Departemen Statistika, Fakultas Matematika, Komputasi, dan Sains Data, Institut Teknologi Sepuluh Nopember (ITS)

Jl. Arief Rahman Hakim, Surabaya 60111 Indonesia

Email:vita_ratna@statistika.its.ac.id

\begin{abstract}
Abstrak-Inflasi merupakan kenaikan harga barang dan jasa secara umum dimana barang dan jasa tersebut merupakan kebutuhan pokok masyarakat atau turunnya daya jual mata uang suatu Negara. Tingkat inflasi/deflasi diukur dari persentase perubahan IHK dan diumumkan ke publik setiap awal bulan oleh BPS yang disebut sebagai Inflasi umum atau inflasi IHK. Inflasi ini merupakan inflasi seluruh barang/jasa yang dimonitor harganya secara periodik. Penelitian ini bertujuan untuk memodelkan inflasi umum bulanan di Indonesia dari Januari 2009 sampai dengan September 2014 dengan model GARCH. Hasil analisis menunjukkan bahwa inflasi di Indonesia dapat dimodelkan menggunakan model ARCH(1). Model ini dibentuk dari data yang sudah tidak mengandung heteroskedastik, artinya varians residual konstan sehingga layak digunakan.
\end{abstract}

Kata Kunci: Inflasi, ARCH, GARCH

\section{PENDAHULUAN}

Inflasi merupakan kenaikan harga barang dan jasa secara umum dimana barang dan jasa tersebut merupakan kebutuhan pokok masyarakat atau turunnya daya jual mata uang suatu Negara [1]. Perubahan (kenaikan) harga suatu barang biasa diukur oleh indicator Indeks Harga Konsumen (IHK), yang dikelompokkan menjadi bahan makanan, makanan jadi, minuman dan tembakau, perumahan, sandang, kesehatan, pendidikan, transportasi dan komunikasi.

Tingkat inflasi/deflasi diukur dari persentase perubahan IHK dan diumumkan ke publik setiap awal bulan oleh BPS yang disebut sebagai Inflasi umum (headline inflation) atau inflasi IHK. Inflasi ini merupakan inflasi seluruh barang/jasa yang dimonitor harganya secara periodik. Sedangkan inflasi umum sendiri merupakan komposit dari inflasi inti, inflasi administered prices dan inflasi volatile goods. Inflasi inti (core inflation) adalah inflasi barang/jasa yang perkembangan harganya dipengaruhi oleh perkembangan ekonomi secara umum, seperti ekspektasi inflasi, nilai tukar, dan keseimbangan permintaan dan penawaran, yang sifatnya cenderung permanen, persistant dan umum. Inflasi ini terdiri atas 692 komoditas, seperti: kontrak rumah, upah buruh, susu, mobil, sepeda motor, dll dimana bobotnya paling besar yaitu sebesar $89,41 \%$. Inflasi administered prices adalah inflasi barang/jasa yang perkembangan harganya secara umum diatur pemerintah, dengan jumlah komoditas sebanyak 21 macam, seperti: tarif listrik, bensin, rokok, dll dimana bobotnya mencapai $18,31 \%$. Inflasi volatile goods adalah inflasi barang/jasa yang perkembangan harganya sangat bergejolak, dimana komoditasnya sebanyak 61 macam, diantaranya: beras, minyak goring, cabe, daging ras, dsb dimana bobotnya sebesar $16,06 \%$.
Secara historis, tingkat dan volatilitas inflasi di Indonesia lebih tinggi dibandingkan Negara-negara berkembang lainnya. Puncak volatilitas inflasi di Indonesia berkaitan dengan kebijakan penyesuaian harga oleh pemerintah. Analisis ekonometrika time series, data yang mempunyai volatilitas tinggi akan sangat riskan untuk digunakan dalam melakukan forecasting [2]. Karena dengan kondisi seperti itu perilaku data time series akan sangat berbeda dengan asumsi yang harus dipenuhi yaitu data time series mempunyai varian gangguan residual (error term) yang konstan dari waktu ke waktu. Istilah yang sering digunakan dalam ekonometrika yaitu varian residual tidak konstan dan berubah-ubah dari satu period eke periode yang lain atau mengandung unsur heteroskedastisitas. Jadi varian residualnya akan berubah-ubah tergantung berapa besar residual di masa lalu.

Terkait dengan adanya volatilitas inflasi, model ARIMA yang biasa digunakan untuk memodelkan data time series akan kurang tepat jika varian residual masih mengandung unsur heteroskedastisitas. Pada tahun 1982, Engle [3] mengembangkan pertama kali model Autoregressive Conditional Heteroskedasticity (ARCH) yang memasukkan unsur error term di masa lalu pada model. Kemudian dikembangkan oleh Bollerslev pada tahun 1986 dengan menambahkan lagi unsur varian error tem di masa lalu sehingga modelnya menjadi Generalized Autoregressive Conditional Heteroskedasticity (GARCH) [4]. Pada penelitian sebelumnya, telah dilakukan aplikasi model ARCH kasus inflasi di Indonesia. Penelitian ini bertujuan untuk memodelkan inflasi umum bulanan di Indonesia dari Januari 2009 sampai dengan September 2014 dengan model GARCH.

\section{BAHAN DAN METODE}

A. Data

Data yang digunakan dalam penelitian ini adalah data Indeks Umum, Inti, Harga Yang Diatur Pemerintah, dan Barang Bergejolak Inflasi Indonesia, Januari 2009Desember 2013, Januari-September 2014 (2012=100) yang dipublish di website Badan Pusat RI (lihat Lampiran 1). Variabel yang digunakan yaitu inflasi umum.

\section{B. Model ARCH/GARCH}

Pada model ekonometrik biasa nilai varians residual diasumsikan sebagai sesuatu yang konstan. Namun kenyataannya seringkali dijumpai kasus dimana terjadi volatilitas sesaat yang cukup tinggi. Dalam hal ini asumsi homoskedastik menjadi tidak terpenuhi sehingga model pada ARIMA yang kita dapatkan kurang tepat untuk diaplikasikan.

Model ARCH/GARCH merupakan model yang memasukkan kemungkinan varians residual yang tidak konstan atau disebut pemodelan heteroskedastisitas. Model 
ini merupakan penyempurnaan dari model ARIMA dimana pada ARIMA varian bukan menjadi pusat perhatian sedangkan model ini melihat pola varian pada residual sehingga model yang dibentuk menjadi lebih tepat dengan varian yang homogen.

Model ARCH (q) dapat dituliskan sebagai berikut:

$$
\text { dimana } \quad \begin{array}{r}
Z_{t}=\hat{Z}_{t}+a_{t} \\
a_{t}=
\end{array}
$$

dan

$$
\sigma_{t}^{2}=\alpha_{0}+\alpha_{1} a_{t-1}^{2}+\ldots .+\alpha_{q} a_{t-q}^{2}
$$

Pada model di atas $a_{t} \sim N\left(0, \sigma_{t}^{2}\right)$ jika $\mathrm{q}>0, \alpha_{0}, \alpha_{\mathrm{i}} \geq 0$ $\operatorname{dan} \sum_{i=1} \alpha_{i}<1$

$a_{t}{ }_{i=1} \quad$ residual

$\alpha_{0} \ldots \alpha_{\mathrm{q}}$ : parameter model ARCH

Perluasan dari model ARCH yaitu model GARCH yang diperkenalkan oleh Bollerslev dimana $\sigma_{\mathrm{t}}{ }^{2}$ merupakan varian periode mendatang berdasarkan informasi masa lalu sehingga disebut conditional mean .

Bentuk model GARCH $(\mathrm{p}, \mathrm{q})$ adalah sebagai berikut:

$\sigma_{t}^{2}=\alpha_{0}+\alpha_{1} a_{t-1}^{2}+\ldots+\alpha_{q} a_{t-q}^{2}+\beta_{1} \sigma_{t-1}^{2}+\ldots+\beta_{p} \sigma_{t-p}^{2}$

dimana $\alpha_{0}>0, \alpha_{\mathrm{i}} \geq 0, \beta_{\mathrm{p}} \geq 0$

$\alpha_{0} \ldots \alpha_{\mathrm{q}}, \beta_{0} \ldots \beta_{\mathrm{q}}$ merupakan parameter model GARCH.

Karena $\sigma_{\mathrm{t}}^{2}$ merupakan varian peramalan untuk periode mendatang berdasarkan informasi masa lalu maka varians tersebut dinamakan conditional variance. Sehingga pada persamaan 2.3 mengandung tiga informasi antara lain:

$\checkmark$ Mean: $\alpha_{0}$

$\checkmark$ Volatilitas pada periode lalu: $a_{t-1}^{2}$ sampai dengan $a_{t-q}^{2}$

$\checkmark$ Varians peramalan pada periode lalu: $\sigma^{2}{ }_{t-1}$ sampai dengan $\sigma^{2}{ }_{t-q}$

C. Estimasi Parameter $\ln r, \alpha, \sigma_{e}^{2}$

Untuk mengetahui adanya efek ARCH/GARCH terlebih dahulu yaitu melakukan estimasi model untuk mean. Selanjutnya menghitung nilai estimasi residual dari mean model yang didapatkan, sehingga $\hat{a}_{t}=Z_{t}-\hat{Z}_{t}$

Kemudian dilakukan identifikasi menggunakan statistuk uji Lagrange-Multiplier Engle dengan cara meregresikan kuadrat residual ke-t terhadap konstanta dan $\mathrm{k}$ lag nilai $a_{t-1}^{2}, a^{2}{ }_{t-2}, \ldots, a_{t-k}^{2}$ sehingga
$a_{t}^{2}=\alpha_{0}+\alpha_{1} a_{t-1}^{2}+\ldots .+\alpha_{k} a_{t-k}^{2}$

dimana nilai k menunjukkan lag maksimum.

Hipotesis untuk menguji ada tidaknya unsur ARCH/GARCH dalam residual mean model adalah:

$$
\begin{aligned}
& \mathrm{H}_{0}: \alpha_{1}=\ldots=\alpha_{k}=0 \\
& \mathrm{H}_{1}: \text { minimal ada satu } \alpha_{q} \neq 0
\end{aligned}
$$

Statistik uji Lagrange Multiplier (LM) adalah sebagai berikut:

$$
\mathrm{LM}=\mathrm{TR}^{2}
$$

dimana $\mathrm{T}$ merupakan koefisien jumlah observasi dan $\mathrm{R}^{2}$ adalah koefisien determinasi pada hasil regresi kuadrat residual ke-t $\left(a_{t}^{2}\right)$ terhadap konstanta dan $\mathrm{k}$ lag nilai $a_{t-1}^{2}, a_{t-2}^{2}, \ldots, a_{t-k}^{2}$

Model dikatakan mengandung unsur heteroskedastik apabila:

$$
T R^{2}>\chi_{(\alpha / 2, k)}^{2}
$$

Sehingga keputusannya tolak $\mathrm{H}_{0}$ dan mengindikasikan bahwa pemodelan ARCH/GARCH dapat dilakukan.

\section{HASIL DAN PEMBAHASAN}

A. Identifikasi Grafik

Sebelum melakukan pemodelan ARCH/GARCH, pertama kali yang dilakukan yaitu identifikasi grafik perkembangan data inflasi dari waktu ke waktu seperti gambar di bawah ini.

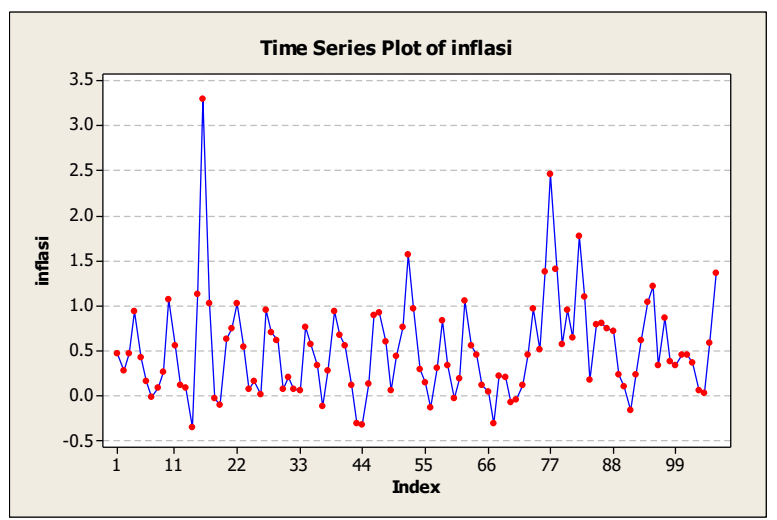

Gambar 1. Grafik ACF dan PACF Data Inflasi

Grafik di atas menunjukkan perkembangan inflasi di Indonesia selama periode Januari 2009 sampai dengan September 2014. Perkembangan laju inflasi tampak bergerak konstan di sekitar rata-rata atau tidak mengandung trend. Artinya dapat disimpulkan bahwa data inflasi di Indonesian pada periode tersebut stasioner terhadap ratarata. Jika diperhatikan dengan lebih teliti tampak adanya volatilitas yang cukup tinggi pada inflasi selama periode penelitian dimana lonjakan tertinggi terjadi pada bulan Juli 2013.

B. Uji Stasioneritas

Santoso [5] menyatakan bahwa data yang stasioner yaitu data yang tidak mengandung akar unit. Salah satu cara mendeteksi adanya akar unit yaitu melalui statistik uji Augmented Dicky Fuller (ADF) dengan $\mathrm{H}_{0}$ menyatakan bahwa data mengandung akar unit, dan diperoleh hasil sebagai berikut:

Tabel 1 Uji Akar Unit Augmented Dicky Fuller (ADF)

Null Hypothesis: INFLASI_U has a unit root

Exogenous: Constant

Lag Length: 1 (Automatic - based on SIC, maxlag=12)

\begin{tabular}{|lll|}
\hline \hline & t-Statistic & Prob.* \\
\hline \hline Augmented Dickey-Fuller test statistic & -7.525379 & 0.0000 \\
\hline Test critical values: $1 \%$ level & -3.495021 & \\
5\% level & -2.889753 & \\
10\% level & -2.581890 & \\
\hline \hline
\end{tabular}

*MacKinnon (1996) one-sided p-values. 
Berdasarkan Tabel 1dengan a sebesar 0,05 diperoleh keputusan tolak $\mathrm{H}_{0}$ karena p-value pada statistik uji t ADF sebesar 0,0000 atau lebih kecil dari $\alpha$ yang artinya data tersebut stasioner, karena tidak mempunyai akar unit. Dalam hal ini data dapat dimodelkan ke dalam bentuk ARMA. Untuk menentukan orde p dan q pada ARMA akan dilihat melalui plot Autocorrelation Function (ACF) dan Partial Autocorrelation Function (PACF).

\section{Estimasi Model ARMA}

Langkah analisis yang digunakan dalam penelitian sebagai berikut.

Dalam melakukan estimasi model ARMA, perlu ditentukan terlebih dahulu ordo (p,q) dari model tentatif yang akan dibentuk. ACF dan PACF digunakan untuk menentukan p pada $\mathrm{AR}(\mathrm{p})$ dan q pada MA(q). Berdasarkan correlogram diperoleh seperti pada Gambar 2 output Minitab di bawah ini.

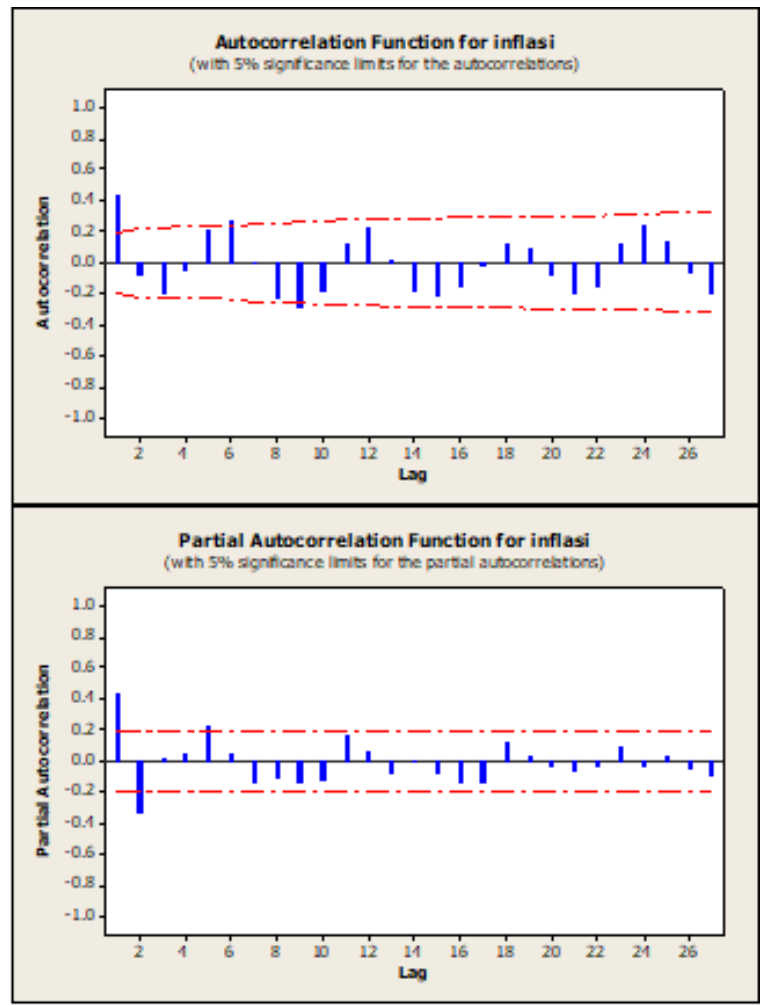

Gambar 2. Grafik ACF dan PACF Data Inflasi

Dari gambar di atas, ordo MA(q) maksimal didapatkan pada lag 1, sedangkan pada ordo $\mathrm{AR}(\mathrm{p})$ maksimal didapatkan ketika garis putus-putus pada lag 1 dan 2, sehingga model tentatif yang dibentuk antara lain: AR(1), AR (2), MA(1), ARMA (1,1), dan ARMA (2,1). Selanjutnya dilakukan estimasi parameter model ARMA berdasarkan model tersebut dan didapatkan hasil seperti Tabel 2.

Tabel 2 Hasil Estimasi Parameter Model ARIMA

\begin{tabular}{|c|c|c|}
\hline \multirow{2}{*}{ Model } & \multicolumn{1}{|c|}{ Persamaan } & $\begin{array}{c}\text { Uji t untuk } \\
\text { masing- } \\
\text { masing } \\
\text { parameter }\end{array}$ \\
\hline AR (1) & $\begin{array}{c}\mathrm{Y}_{\mathrm{t}}=0,28493+0,4442 \mathrm{Y}_{\mathrm{t}-} \\
1+\mathrm{e}_{\mathrm{t}}\end{array}$ & signifikan \\
\hline
\end{tabular}

\begin{tabular}{|c|c|c|}
\hline Model & Persamaan & $\begin{array}{l}\text { Uji t untuk } \\
\text { masing- } \\
\text { masing } \\
\text { parameter }\end{array}$ \\
\hline MA (1) & $\begin{array}{l}Y_{t}=0,51057+e_{t}-0,5859 \\
e_{t-1}\end{array}$ & signifikan \\
\hline AR (2) & $\begin{array}{l}Y_{t}=0,38424+0,6008 Y_{t-1} \\
-0,3545 Y_{t-2}+e_{t}\end{array}$ & signifikan \\
\hline $\begin{array}{l}\text { ARMA } \\
(1,1)\end{array}$ & $\begin{aligned} \mathrm{Y}_{\mathrm{t}}= & 0,47053+0,0797 \mathrm{Y}_{\mathrm{t}-1} \\
& +\mathrm{e}_{\mathrm{t}}-0,5369 \mathrm{e}_{\mathrm{t}-1}\end{aligned}$ & $\begin{array}{c}\text { AR tidak } \\
\text { signifikan } \\
\text { MA } \\
\text { signifikan }\end{array}$ \\
\hline $\begin{array}{l}\text { ARMA } \\
(2,1)\end{array}$ & $\begin{array}{l}\mathrm{Y}_{\mathrm{t}}=0,025939+1,2787 \mathrm{Y}_{\mathrm{t}-} \\
1-0,3266 \mathrm{Y}_{\mathrm{t}-2}+\mathrm{e}_{\mathrm{t}}+ \\
0,9964 \mathrm{e}_{\mathrm{t}-1}\end{array}$ & signifikan \\
\hline
\end{tabular}

Dari tabel di atas, model ARMA $(1,1)$ koefisien AR dan MA tidak signifikan pada pengujian koefisien melalui statistik uji t. Oleh karena itu, selanjutnya hanya 4 model yang dipertimbangkan untuk pengujian ketepatan model.

D. Pengujian Ketepatan Model

Setelah berhasil menaksir nilai-nilai parameter dari model yang didapatkan sementara, selanjutnya perlu dilakukan pemeriksaan diagnostik agar model tersebut dikatakan cukup memadai. Untuk menguji kelayakan model yang telah ditetapkan digunakan uji Ljung-Box di bawah hipotesis nol yaitu autokorelasi sisaan tidak berbeda nyata dari nol dimana statistik $Q$ yang berdistribusi $\chi^{2}{ }_{(\mathrm{K}-\mathrm{m})}$ sebagai berikut [6], [7]:

$$
\mathrm{Q}=\mathrm{n}(\mathrm{n}+2) \sum_{\mathrm{k}=1}^{\mathrm{K}} \frac{\mathrm{r}_{\mathrm{k}}^{2}}{\mathrm{n}-\mathrm{k}}
$$

dengan:

$$
\begin{aligned}
& \mathrm{n} \text { : banyaknya pengamatan } \\
& \mathrm{r}_{\mathrm{k}} \text { : koefisien autokorelasi nilai sisa pada lag } \mathrm{k} \\
& \mathrm{K} \text { : lag maksimum } \\
& \mathrm{m} \text { : jumlah parameter yang diduga dalam model }
\end{aligned}
$$

Apabila statistik $Q$ lebih kecil dari $\chi_{(\mathrm{K}-\mathrm{m})}$, maka dapat dikatakan bahwa model yang didapat sudah layak. Pada model yang kita dapatkan, melalui bantuan software Minitab 16 diperoleh hasil uji statistik Ljung-Box seperti dibawah ini.

Tabel 3 Uji Kelayakan Model ARMA

\begin{tabular}{|l|c|l|c|}
\hline \multicolumn{1}{|c|}{ Model } & $\begin{array}{c}\text { Uji Ljung- } \\
\text { Box }\end{array}$ & \multicolumn{1}{|c|}{ Kesimpulan } & AIC \\
\hline AR (1) & $\begin{array}{c}\text { p-value }< \\
0,05\end{array}$ & $\begin{array}{l}\text { Model tidak } \\
\text { layak }\end{array}$ & 1,457792 \\
\hline MA (1) & $\begin{array}{c}\text { p-value }< \\
0,05\end{array}$ & $\begin{array}{l}\text { Model tidak } \\
\text { layak }\end{array}$ & 1,350711 \\
\hline AR (2) & $\begin{array}{c}\text { p-value }> \\
0,05\end{array}$ & Model layak & 1,363087 \\
\hline ARMA & $\begin{array}{c}\text { p-value }< \\
(2,1)\end{array}$ & $\begin{array}{l}\text { Model tidak } \\
\text { layak }\end{array}$ & 1,382202 \\
\hline
\end{tabular}


Pemilihan model terbaik dari hasil diatas adalah model yang sudah layak yaitu $\mathrm{AR}(2)$ karena memiliki p-value lebih besar dari 0,05 .

\section{E. Pengujian Heteroskedastisitas}

Hasil estimasi model AR(2) yang kita dapatkan belum memasukkan unsur ARCH/GARCH pada model, untuk itu perlu dilakukan pengujian heteroskedastisitas melalui statistik uji LM pada persamaan 2.5. Dalam hal ini pengujian dilakukan dengan bantuan software Eviews 7.

Tabel 4 Uji ARCH LM

\begin{tabular}{|c|c|c|c|}
\hline \multicolumn{4}{|c|}{ Heteroskedasticity Test: ARCH } \\
\hline $\begin{array}{l}\text { F-statistic } \\
\text { Obs*R- } \\
\text { squared }\end{array}$ & $\begin{array}{l}6.252026 \\
6.001830\end{array}$ & $\begin{array}{l}\text { Prob. F(1,100) } \\
\text { Prob. Chi- } \\
\text { Square(1) }\end{array}$ & 0.0140 \\
\hline
\end{tabular}

Pada Tabel 4 dapat dilihat bahwa probabilitas chisquare dengan pada lag $1(\mathrm{k}=1)$ sebesar 0,0143 dimana nilai tersebut lebih kecil dari $0,025(\alpha / 2)$ sehingga dapat disimpulkan bahwa model yang kita bentuk mengandung unsur heteroskedastik.

\section{F. Pemodelan ARCH/GARCH}

Untuk mengetahui lag dalam pemodelan ARCH/GARCH maka dapat digunakan dengan melihat plot ACF dan PACF dari kuadrat residual. Hasil plot ACF dan PACF dari kuadrat residual model AR(2) seperti pada Gambar 3.

Dari tersebut dapat dilihat bahwa plot ACF nyata pada lag 1 dan PACF nyata pada lag 1 pula. Seperti halnya pada pembentukan model ARIMA, model tentatif yang dapat dibentuk untuk data inflasi yang memasukkan unsur ARCH/GARCH antara lain: ARCH(1), GARCH(1), dan GARCH (1,1). Dengan bantuan software Eviews estimasi parameter model GARCH dapat dilakukan dengan hasil sebagai berikut.

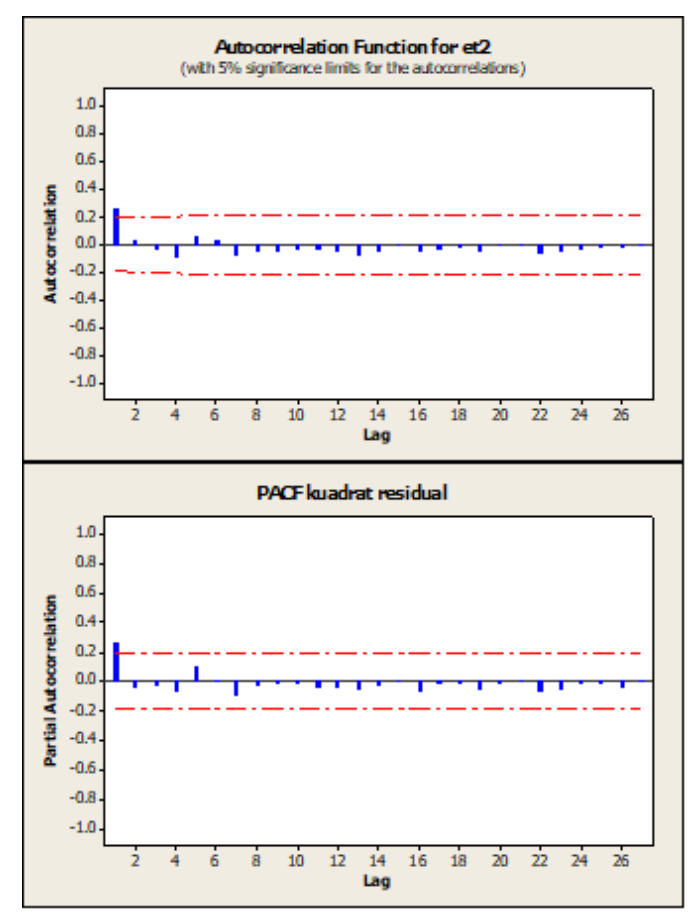

Gambar 3. Plot ACF dan PACF Kuadrat Residual
Tabel 5. Estimasi Parameter Model ARCH(1)

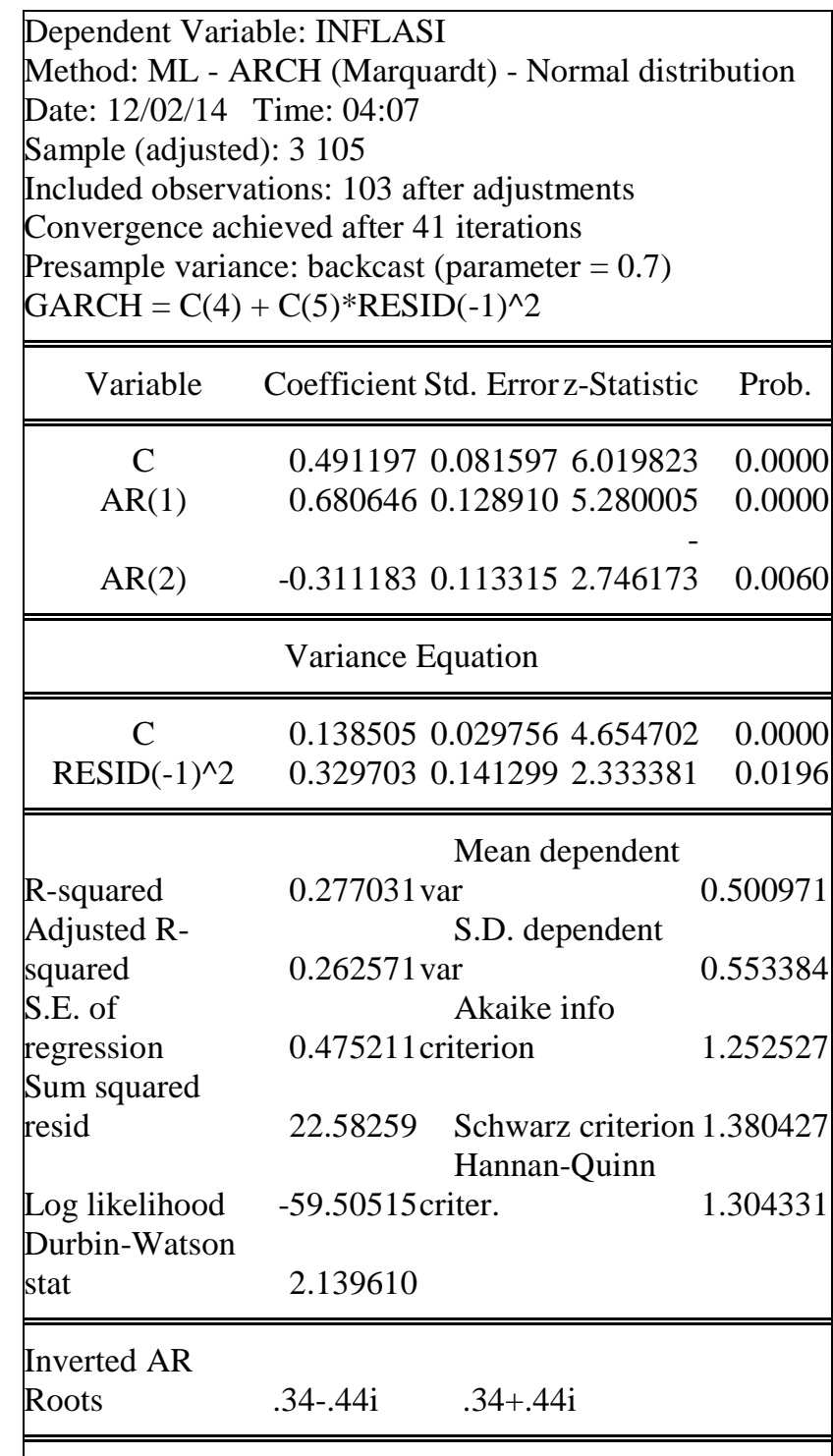

Dari ketiga model di atas, dapat dilihat bahwa hanya model ARCH(1) yang estimasi parameter dari ARCH signifikan pada $\alpha$ sebesar 0,05 , artinya model ARCH(1) dikatakan layak untuk kasus inflasi pada periode penelitian. Jika diperhatikan dari nilai AIC pada model yang sebelumnya diperoleh yaitu AR(2) sebesar 1.363087 (Lampiran 3). Pada model AR yang melibatkan unsur ARCH nilai AIC yang diperoleh sebesar 1.252527 dimana nilainya lebih kecil dibandingkan pada model AR(2). Semakin kecil nilai AIC maka model tersebut semakin bagus. Hal ini mengindikasikan bahwa model inflasi pada periode penelitian yang melibatkan ARCH lebih baik dibandingkan yang sebelumnya.

Untuk membuktikan bahwa model yang didapatkan sudah tidak mengandung heteroskedastik dapat dilakukan melalui pengujian ARCH-LM seperti pada identifikasi yang sebelumnya. Hasil pengujiannya seperti tampak pada Tabel 8. 
Tabel 6. Estimasi Parameter Model GARCH(1)

Dependent Variable: INFLASI

Method: ML - ARCH (Marquardt) - Normal distribution

Date: 12/02/14 Time: 04:08

Sample (adjusted): 3105

Included observations: 103 after adjustments

Convergence achieved after 42 iterations

Presample variance: backcast (parameter $=0.7$ )

$\mathrm{GARCH}=\mathrm{C}(4)+\mathrm{C}(5) * \mathrm{GARCH}(-1)$

\begin{tabular}{|c|c|c|}
\hline Variable & Coefficient Std. Error z-Statistic & Prob. \\
\hline $\mathrm{C}$ & 0.5043650 .0806996 .249939 & 0.0000 \\
\hline $\operatorname{AR}(1)$ & $\begin{array}{lll}0.591381 & 0.069493 & 8.509907\end{array}$ & 0.0000 \\
\hline \multirow[t]{2}{*}{$\operatorname{AR}(2)$} & -0.3435900 .1135503 .025900 & 0.0025 \\
\hline & \multicolumn{2}{|l|}{ Variance Equation } \\
\hline \multirow{2}{*}{$\begin{array}{c}\mathrm{C} \\
\text { GARCH(-1) }\end{array}$} & \multirow{2}{*}{$\begin{array}{lll}0.056475 & 0.197591 & 0.285815 \\
0.742909 & 0.921600 & 0.806108\end{array}$} & 0.7750 \\
\hline & & 0.4202 \\
\hline \multirow{7}{*}{$\begin{array}{l}\text { R-squared } \\
\text { Adjusted R- } \\
\text { squared } \\
\text { S.E. of } \\
\text { regression } \\
\text { Sum squared } \\
\text { resid }\end{array}$} & \multicolumn{2}{|l|}{ Mean dependent } \\
\hline & \multirow{2}{*}{$\begin{array}{l}0.288131 \text { var } \\
\text { S.D. dependent }\end{array}$} & \multirow[t]{2}{*}{0.500971} \\
\hline & & \\
\hline & 0.273893 var & 0.553384 \\
\hline & \multicolumn{2}{|l|}{ Akaike info } \\
\hline & 0.471549 criterion & 1.393681 \\
\hline & $\begin{array}{ll}22.23588 & \text { Schwarz criterion } \\
& \text { Hannan-Quinn }\end{array}$ & 1.521580 \\
\hline \multirow{2}{*}{$\begin{array}{l}\text { Log likelihood } \\
\text { Durbin-Watson } \\
\text { stat }\end{array}$} & -66.77456 criter. & \multirow[t]{2}{*}{1.445484} \\
\hline & 1.981389 & \\
\hline \multicolumn{3}{|l|}{ Inverted AR } \\
\hline
\end{tabular}

ari hasil pengujian diatas nilai probabilitas Chi-Square lebih besar dari 0,025 maka dapat disimpulkan bahwa model ARCH(1) yang dibentuk dari data inflasi sudah tidak mengandung heteroskedastik, artinya varians residual konstan.

Tabel 8. Uji ARCH-LM pada Model ARCH(1)

\begin{tabular}{|c|c|c|c|}
\hline \multicolumn{4}{|c|}{ Heteroskedasticity Test: ARCH } \\
\hline F-statistic & 0.061531 & Prob. $\mathrm{F}(1,100)$ & 0.8046 \\
\hline Obs*R-squared & 0.062723 & Prob. Chi-Square(1) & 0.8022 \\
\hline
\end{tabular}

\section{KESIMPULAN}

Berdasarkan hasil analisa dan pembahasan, didapatkan kesimpulan bahwa data inflasi di Indonesia dapat dimodelkan menggunakan model $\mathrm{ARCH}(1)$. Model ini dibentuk dari data yang sudah tidak mengandung heteroskedastik, artinya varians residual konstan sehingga layak digunakan.

Tabel 7. Estimasi Parameter Model GARCH(1,1)

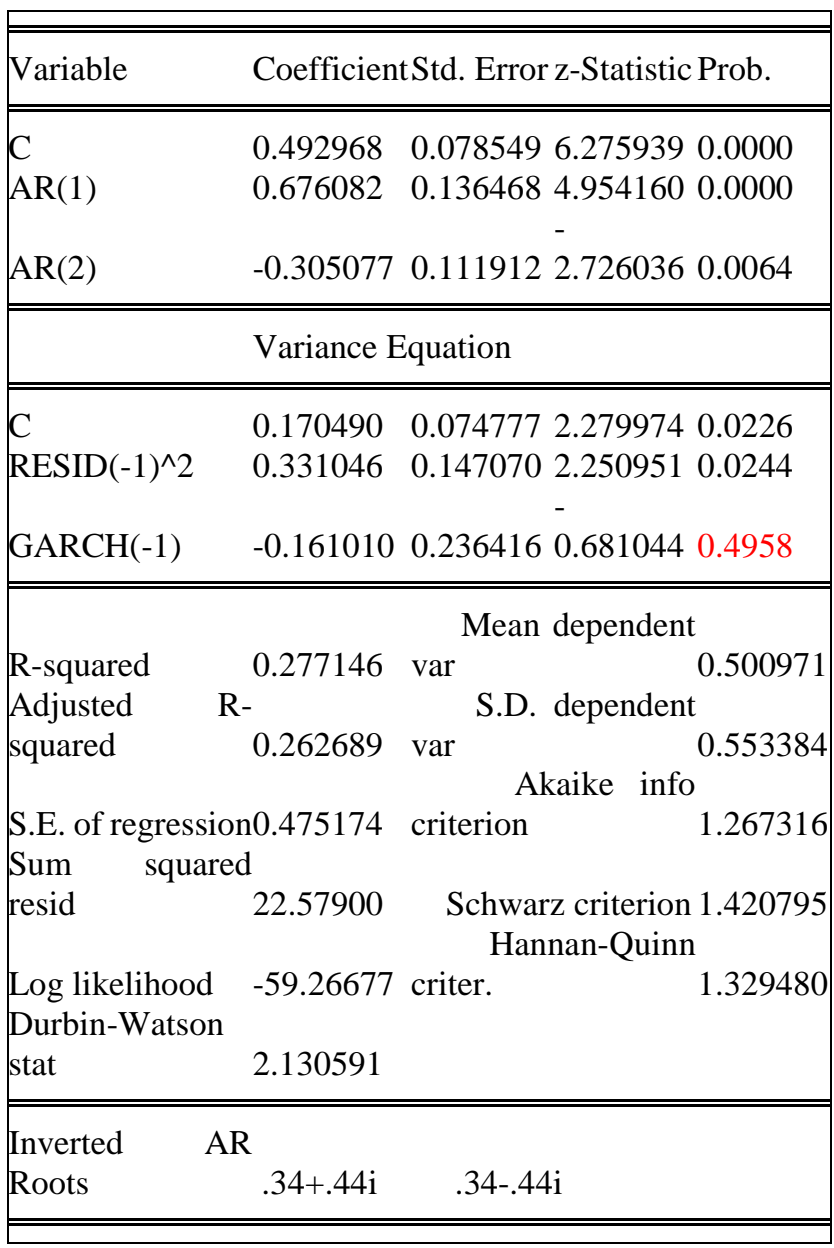

DAFTAR PUSTAKA

[1] L. P. Widasari and N. Wahyuningsih, "Aplikasi Model ARCH-GARCH dalam Peramalan Tingkat Inflasi," Jurnal Sains dan Seni POMITS, vol. 1, no. 1, 2012.

[2] A. Widarjono, "Aplikasi Model ARCH Kasus Tingkat Inflasi di Indonesia," Jurnal Ekonomi Pembangunan, 2002.

[3] R. F. Engle, "Autoregressive conditional heteroscedasticity with estimates of the variance of United Kingdom inflation," Econometrica: Journal of the Econometric Society, pp. 987-1007, 1982.

[4] T. Bollerslev, "Generalized autoregressive conditional heteroskedasticity," Journal of econometrics, vol. 31, no. 3, pp. 307-327, 1986.

[5] T. Santoso, Aplikasi Model GARCH pada Data Inflasi Bahan Makanan Indonesia. Yogyakarta: Universitas Gadja Mada, 2011.

[6] W. S. William, "Wei, 2006. Time Series Analysis: Univariate and Multivariate Methods." Pearson Education Inc.

[7] A. A. R. Fernandes, Handout Kuliah Peramalan. Malang: Universitas Brawijaya, 2006. 
Lampiran 1. Data Inflasi Umum Indonesia Januari 2009 - September 2014

\begin{tabular}{|c|c|c|c|c|c|}
\hline Tahun 2009/Bulan & Inflasi & Tahun 2010/Bulan & Inflasi & Tahun 2011/Bulan & Inflasi \\
\hline Januari & -0.07 & Januari & 0.84 & Januari & 0.89 \\
\hline Februari & 0.21 & Februari & 0.30 & Februari & 0.13 \\
\hline Maret & 0.22 & Maret & -0.14 & Maret & -0.32 \\
\hline April & -0.31 & April & 0.15 & April & -0.31 \\
\hline Mei & 0.04 & Mei & 0.29 & Mei & 0.12 \\
\hline Juni & 0.11 & Juni & 0.97 & Juni & 0.55 \\
\hline Juli & 0.45 & Juli & 1.57 & Juli & 0.67 \\
\hline Agustus & 0.56 & Agustus & 0.76 & Agustus & 0.93 \\
\hline September & 1.05 & September & 0.44 & September & 0.27 \\
\hline Oktober & 0.19 & Oktober & 0.06 & Oktober & -0.12 \\
\hline November & -0.03 & November & 0.60 & November & 0.34 \\
\hline Desember & 0.33 & Desember & 0.92 & Desember & 0.57 \\
\hline Tahun 2012/Bulan & Inflasi & Tahun 2013/Bulan & Inflasi & Tahun 2014/Bulan & Inflasi \\
\hline Januari & 0.76 & Januari & 1.03 & Januari & 1.07 \\
\hline Februari & 0.05 & Februari & 0.75 & Februari & 0.26 \\
\hline Maret & 0.07 & Maret & 0.63 & Maret & 0.08 \\
\hline April & 0.21 & April & -0.10 & April & -0.02 \\
\hline Mei & 0.07 & Mei & -0.03 & Mei & 0.16 \\
\hline Juni & 0.62 & Juni & 1.03 & Juni & 0.43 \\
\hline Juli & 0.70 & Juli & 3.29 & Juli & 0.93 \\
\hline Agustus & 0.95 & Agustus & 1.12 & Agustus & 0.47 \\
\hline September & 0.01 & September & -0.35 & September & 0.27 \\
\hline Oktober & 0.16 & Oktober & 0.09 & & \\
\hline November & 0.07 & November & 0.12 & & \\
\hline Desember & 0.54 & Desember & 0.55 & & \\
\hline
\end{tabular}

